\section{Nationality Diversity of Bank Boards}

\author{
Miroslav Nedelchev \\ Economic Research Institute, Bulgarian Academy of Sciences, Bulgaria \\ mknedelchev@abv.bg
}

\begin{abstract}
The aim of this paper is to carry out a comparative study for nationality diversity in bank boards. The study covers practices of board diversity of nine commercial banks. The data are compared for subsidiary banks in Bulgaria and their parent banks from the home country. The study defines a high degree of nationality diversity in subsidiary banks. The Bulgarian banks have a higher number of foreign members on boards compared to their parent banks. The good practices on board diversity in Bulgarian banks are a consequence of their subordination in European financial conglomerates and are aimed to reduce agent conflicts.
\end{abstract}

Keywords: corporate governance, subsidiary banks, Bulgaria, comparative study

\section{Introduction}

The effects of financial crisis reveal weaknesses in corporate governance of banks and highlight the need to balance independence and competences of boards (European Commission, 2010). The application of good corporate governance practices, including diversity of board composition and structure, will increase the competitiveness and sustainability of banks in the long run (European Commission, 2012).

The diversity policy concerns recruitment of new board members and has impact on fit and proper test for managers (European Banking Authority, 2017). The diversity reflects the competences and views of board members. The low level of board diversity leads to a process called „group thinking”, reducing debates, ideas and disputes in the decision-making process and ineffective supervision of managers (Čančer \& Mulej, 2013).

The diversity of a board contributes to weakening the phenomenon of „herd behavior" (European Banking Authority, 2016). Increasing diversity enables facilitation of understanding of the institution's activities and to ensure decision-making in an objective and constructive manner. Diversity can help to make better and more effective decisions about strategies and risk-taking, as members have the opportunity to benefit from a wider range of views, experiences, perceptions and values.

The main objective of this study is to compare the board diversity by nationality in subsidiary banks in Bulgaria and their parent banks in the home country. Using quantitative data processing methods, the study achieves qualitative conclusions about the practices of nine banks. The data sources are Bulgarian National Bank and European Banking Authority.
ORIGINAL SCIENTIFIC PAPER

RECEIVED: NOVEMBER 2017

REVISED: FEBRUARY 2018

ACCEPTED: FEBRUARY 2018

DOI: 10.2478/ngoe-2018-0001

UDK: 336.71.025.13(497.2)

JEL: G21, G34, M14

Citation: Nedelchev, M. (2018).

Nationality Diversity of Bank Boards. Naše gospodarstvo/Our Economy, 64(1), 3-10. DOI: 10.2478/ngoe-2018-0001

\section{NG OE}

NAŠE GOSPODARSTVO OUR ECONOMY

\begin{tabular}{l|l|l} 
Vol. 64 & No.1 2018
\end{tabular}

pp. $3-10$ 
The innovative nature of the diversity issue determines the limitations for our study: there is only one legislative source of information, the EU directives to reduce effects of the international financial crisis; otherwise, there is a small volume of published empirical data and scarce specialized literature. In accordance with the measures for prevention of future crisis in the EU, we formulated the following research hypotheses:

H1: Nationality diversity of boards aims to increase the competitiveness and sustainability of banks;

H2: Parent banks have a higher level of nationality diversity of boards than their subsidiary banks considering that they are: registered in the euro area, covered under EU directives and listed on stock exchanges.

The structure of this study consists of three parts. In the first part is presented the emergence and development of concept for board diversity in the EU; in the second one, we consider the expected effects of this process; and the third part contains an empirical study, on the basis of which some basic findings are made. Finally, the findings of the study are specified and recommendations are given for future research.

\section{Emergence and Development of Diversity in Bank Boards}

Globalization strengthens and accelerates the process of capital exports, which is why the need for supervising abroad managers for fiduciary duties is growing. Another process, the European integration, has placed a third function of diversified boards on the agenda-knowledge of local legislation and customer preferences. For some countries from Eastern Europe, the adoption of market principles in the 1990s and the entry of foreign ownership into the banking system have further influenced the development of board diversity.

In the EU was adopted a board diversity policy as a measure to reduce the effects of recent financial crises; among them, the leading causes are managers' behavior and, in particular, the lack of board control over managers' appetite for risk (Basel Committee on Banking Supervision, 2010). Although the data on foreign presentation in boards in the EU Member States are positive-1/3 of their members are foreign citizens (European Commission, 2011) and despite the adopted directives and harmonization process, the different levels of nationality board diversity in some cases are significant, from 54\% for the Netherlands to $2 \%$ for Spain (IIC Partners, 2015).
The diversity of bank boards arises in 2002 under the Sarbanes-Oxley Act in the USA through requirements to increase the presentation of women, minorities, young managers and persons without bank practice (Björklund, 2010).

In 2009, radical steps have been taken in the EU to reformat good corporate governance practices and focus on protecting stakeholders rather than shareholders. Because of the introduction of measures to protect taxpayers and stakeholders since 2013, the EU banks are required to adopt an own corporate policy on board diversity to prevent future crises. The basic principles of diversity enforcement control are the classic „comply-or-explain” principle, the opinion by external auditors for reached results, and the good practice data by competent authorities. The issue of the importance of board diversity on reforms for good corporate governance practices is found in several documents:

- The European Commission published its „Green paper: Corporate governance in financial institutions and remuneration policies" (European Commission, 2010), which includes measures to tackle the effects of financial crises. The main reason for crisis is the lack of effective control by boards over managers and, accordingly, insufficient resources to assess risks. A direct reflection of this disadvantage is found in the lack of diversity in social and personal characteristics of the board (gender, social and cultural background, education, nationality).

- In „Action Plan: European company law and corporate governance - a modern legal framework for more engaged shareholders and sustainable companies” (European Commission, 2012), the European Commission sets requirements for greater transparency regarding diversity policy and clarifies the Green paper's (2010) terminology. The initiative is complementary to the proposal to improve diversity for non-executive board members of listed companies only.

- The Directive 2013/36/EU makes recommendations for encouraging independent opinion and facilitating constructive criticism in boards. In the appointment of board members, the Member States and competent authorities should require banks and nomination committees to take into account a wide range of criteria for skills and abilities held by applicants. To this end, the banks need to develop policies to promote diversity in the boards in terms of age, gender, nationality, education and professional experience. The Directive includes the following requirements: the financial intermediaries to establish a nomination committee that identifies and recommends for approval of the board or the general meeting of shareholders the filling of seats in management bodies, taking into account the balance of knowledge, skills, diversity and experience of board members; the financial institutions to develop a policy to promote 
diversity in boards; and the competent authorities of the Member States to provide information on the diversity to the European Banking Authority to compare diversity practices at the EU level.

- The European Banking Authority provides a summary of diversity of boards in the European Union since 2016 (European Banking Authority, 2016). The data of national competent authorities are processed and compared to improve the good practices of individual banks. Diversity of nationality is of particular importance to overseas banks, as they combine business activity and expertise in the relevant market. The nationality diversity allows a board to take better account of cultural values, as well as legal and market circumstances.

\section{Effects of Board Diversity}

During the latest financial crisis, it became clear that corporate governance had not functioned as expected (Pašić, Bratina and Festić, 2016). The recommendations contained in the EU directives (Directive 2013/36/EU, Directive 2014/59/EU, Directive 2014/65/EU) on the diversity of bank boards are related to the achievement of the following expected effects:

- effective risk control and sustainability of financial institutions;

- independently viewing and facilitating of constructive criticism;

- balance of knowledge, skills and experience of board members;

- balance between independence and competences of board members;

- $\quad$ objectivity and independence in assessing the qualities of members in order to exercise control over efficiency of management;

- $\quad$ sound and prudent management, promoting market integrity and protecting investors' interests;

- understanding of the bank's activities, including the main risks;

- avoiding ,group thinking”;

- adequate representation of the population;

- understanding of cultural values, market peculiarities and legal frameworks.

There is a recommendation to add several forms of diversity for achieving greater effects (García-Mecaa et al., 2015). The tendency is a composition of boards to achieve diversity in terms of:

- age;

- gender;

- nationality;

- education and professional experience.
An additional form of diversity is a representation of employees and workers in management. This is an appropriate way to promote diversity by adding a key point of view and real knowledge of the institution's internal functioning.

\section{Nationality Diversity of Bank Boards: The Bulgarian Practice}

The European Commission's recommendations on diversity are primarily related to non-executive members of bank boards (European Commission, 2011). Diversity policies refer to the members of a supervisory board in a two-tier system and to the non-executive members of a board of directors in a one-tier system (Nedelchev, 2017b). The majority of Bulgarian banks are with foreign ownership, which explains the prevalence of two-tier management systems in Bulgaria (Nedelchev, 2017a).

The Bulgarian National Bank identifies nine Bulgarian banks as subsidiaries of European financial groups: Allianz Bank Bulgaria, DSK Bank, EIBank, Eurobank Bulgaria, Procredit Bank Bulgaria, Raiffeisen Bank, Societe Generale Expressbank, Unicredit Bulbank, and United Bulgarian Bank (Bulgarian National Bank, 2017). These banks have an average of 5.4 persons as the number of board members. The largest number of board members (seven natural persons, i.e., the maximum number of members foreseen in a supervisory board under the national legislation) has banks from Germany and Italy (Figure 1).

The bank boards in Bulgaria are over-internationalized. The average percentage of Bulgarian members on boards is relatively low (12\%), which can be explained by the high foreign share in bank ownership. In more than half of Bulgarian banks, the chairman of the board is a foreign citizen.

Procredit Bank Bulgaria has the most Bulgarian members on the board (40\%), and in four banks (DSK Bank, EIBank, Raiffeisen Bank and United Bulgarian Bank), the boards are entirely foreign (Figure 2).

The majority of Bulgarian banks (73\%) are overseas subsidiaries of banking groups from the EU; these groups are listed on stock exchanges and are within the scope of EU directives, as they are registered in the Euro area (Houbenova-Delisivkova, 2015). The nationality diversity in subsidiary banks is a fact: $88 \%$ of board members are foreign citizens, while in parent banks, $27 \%$ are foreign (Figure 3).

Depending on the origin of capital, the banking boards in Europe fall within two types and differ in their function 
Figure 1. Foreign subsidiary banks in Bulgaria

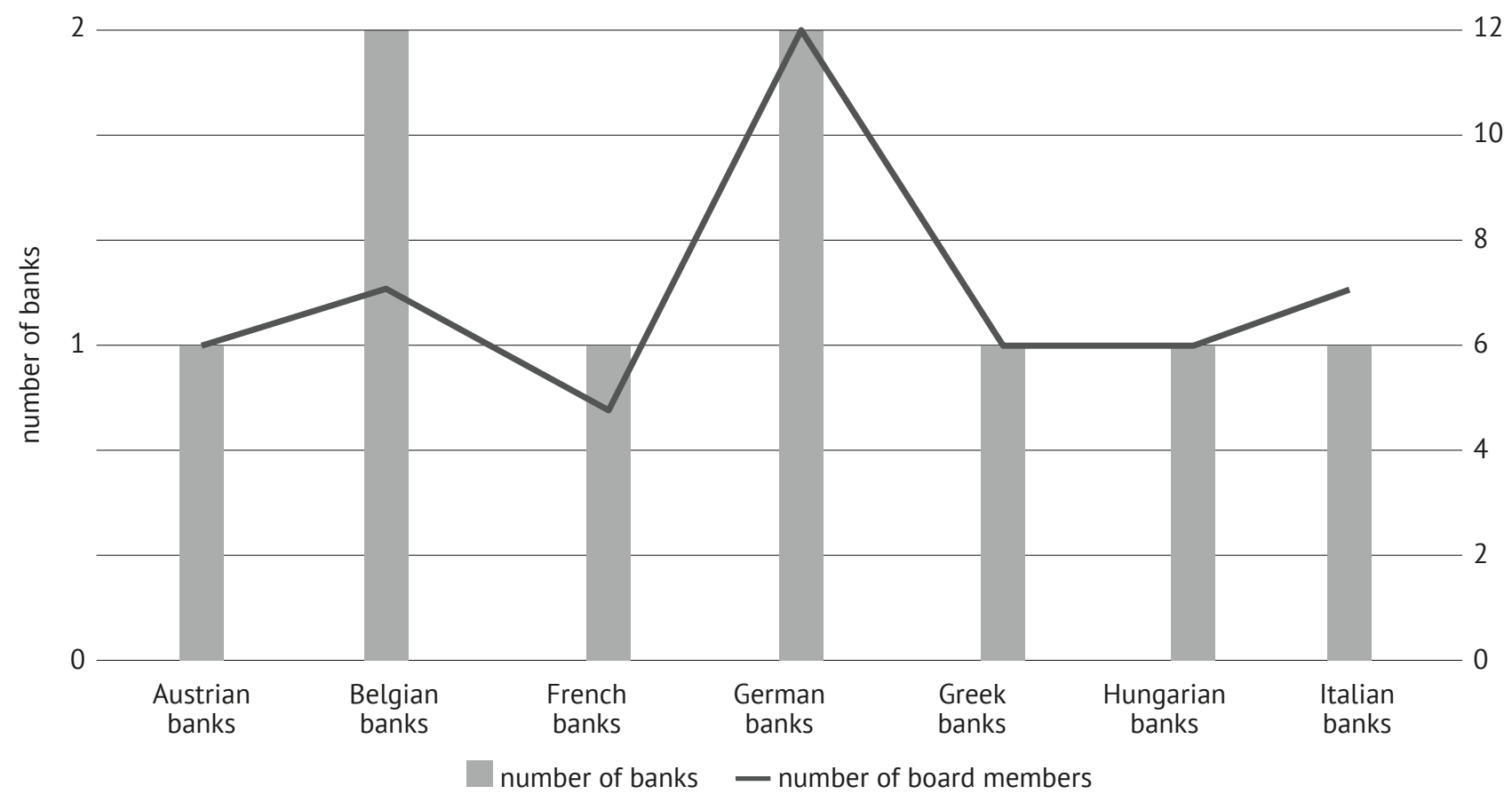

Source: Bulgarian National Bank, 2017

Figure 2. Nationality diversity of bank boards in Bulgaria

$$
10
$$

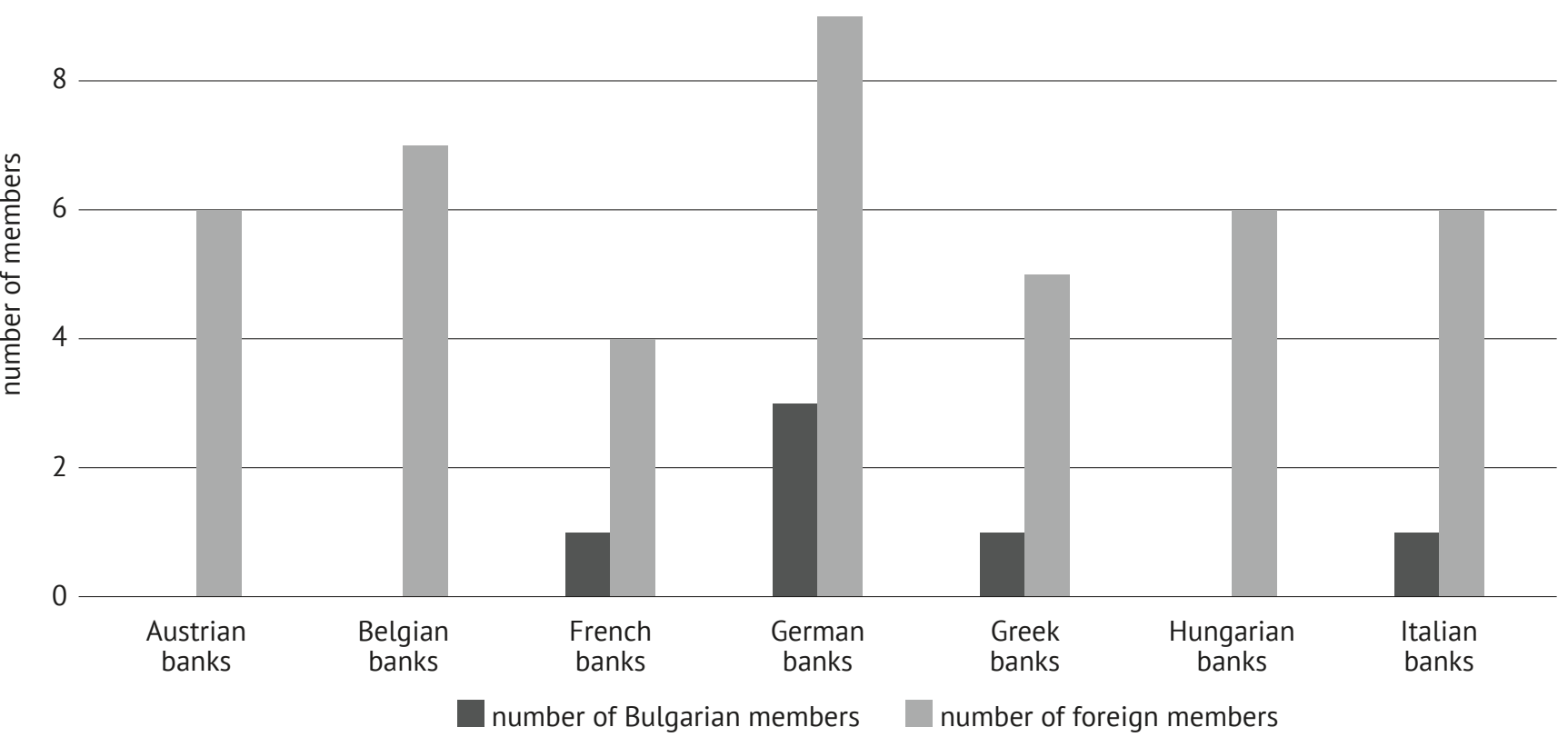

Source: Bulgarian National Bank, 2017

(International Finance Corporation, 2012). In banks with local capital, the boards are created to comply with regulatory requirements rather than to add value to bank operations. For banks with foreign capital, the boards are formality; they focus on implementing the decisions of the head offices and establishing close relationships with management without sufficient knowledge of the local environment. In subsidiary banks, the foreign board members reflect the origin of capital, and in parent banks, their own professionalism (Figure 4). 
Figure 3. Nationality diversity of boards in Bulgarian subsidiary banks and their parent banks

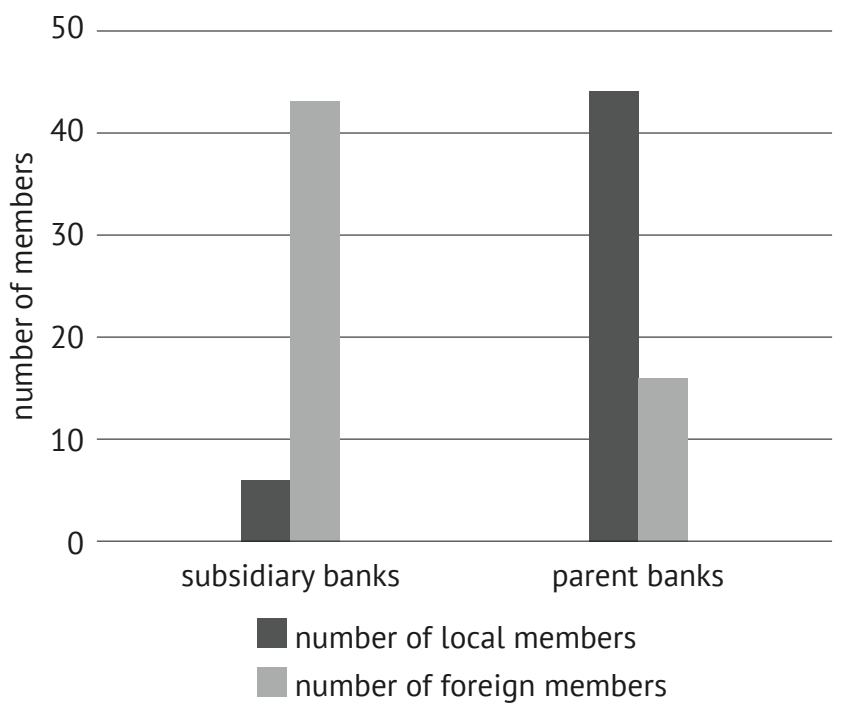

Source: Bulgarian National Bank, 2017
Figure 5. Number of foreign members in Bulgarian bank boards

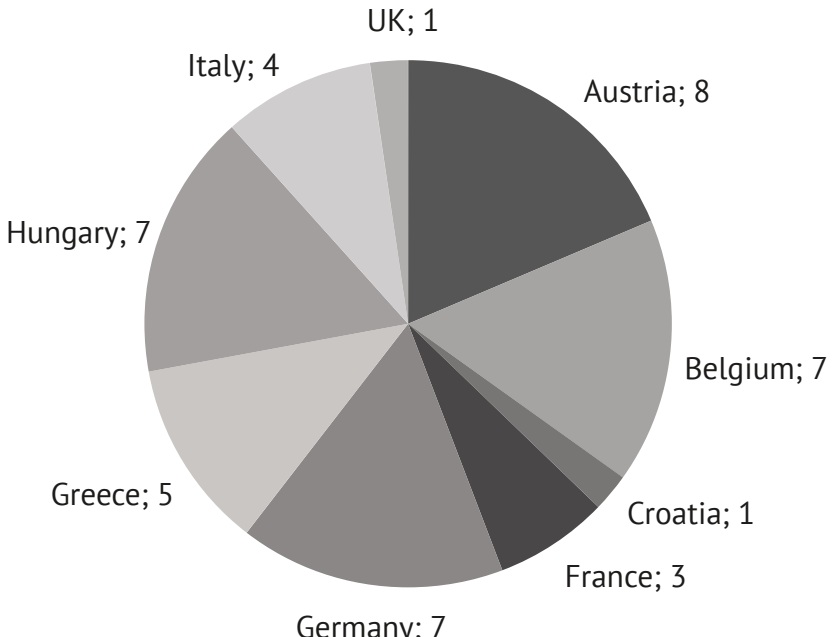

Source: Bulgarian National Bank, 2017

Figure 4. Nationality of foreign board members in Bulgarian subsidiary banks and their parent banks

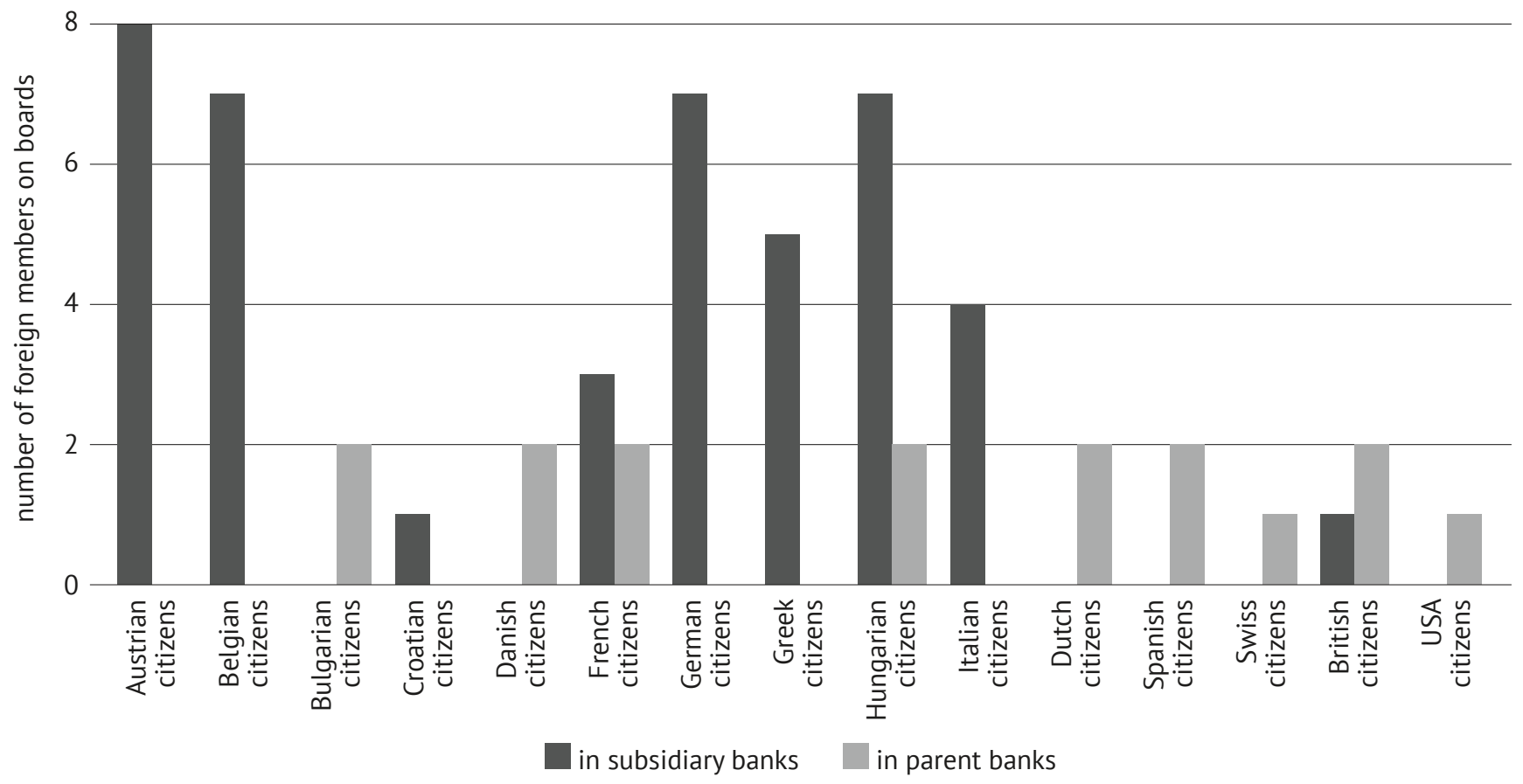

Source: Bulgarian National Bank, 2017

All foreign ownership in Bulgarian bank system is from the EU. In cases of five banks (DSK bank, EIBank, Procredit bank Bulgaria, Raiffeisen bank Bulgaria, United Bulgarian bank), the foreign board members are from the home country. In some cases, there are foreign board members outside the home country who reflect the structure of financial groups, i.e., a board member from the country of the holding group for decline of contagion risk (Allianz bank
Bulgaria, Eurobank Bulgaria, Societe Generale Expessbank, Unicredit Bulbank). In the case of TBI Bank, there are board members from the home country, the Netherlands, and one board member from the ultimate home country (Israel).

The nationality of board members of Bulgarian banks indicates the home country and, more precisely, the vertical structure of capital investments (Figure 5). 
The adopted policy for board diversity is individualized for each Member State and despite the statutory requirements throughout the EU, the proportion of institutions conducting such policies is small (35.5\%). For Bulgaria as a host country, the banks with adopted diversity policies are $26.7 \%$, i.e., close to the average in the home country (29\%) (Figure 6).

\section{Conclusions and Recommendations}

The importance of diversity of boards has arisen at the beginning of 21st century and more concretely, the need for gender diversity. At the core of diversity are social expectations and more often, political initiatives rather than scientific research. Irrespective of the form of diversity, the policy initiatives in this area outweigh the economic reality without satisfying the social needs that stir up public mistrust. The main reason for the mistrust of political initiatives for board diversity is the lack of quantitative measures for the achieved quality results.

In order to reduce the effects of a financial crisis and to prevent future crises, it is necessary to achieve diversity in bank boards. In this context, there are recommendations in the EU for good corporate governance practices to include reporting for the level of diversity that would improve the decision-making process and risk management.

The recommendations in EU directives for diversity include quality effects that can be identified in the medium and long term. The expected effects of diversity are defined as being of a qualitative nature. Quantitative measures are not provided in EU directives and national policies for determining the contributions of diversity on boards. It is recommended to introduce a set of conventional indicators for conducting international comparative analyses provided by EU directives within the remit of national competent authorities and European Banking Authority.

Our results partially support the first hypothesis $(H 1)$ - there is likely an increasing competitiveness and sustainability for parent banks only. The nationality diversity in boards of subsidiary banks is two types: members from home country and occasionally, from country where is registered the holding group. We assume there are different aims of nationality diversity of boards in subsidiary banks: protection of ownership (of the bank's equity) abroad, repatriation of profit, prevention of contagion risk and generation of management staff. To confirm the assumptions, we recommend a qualitative meta-study be carried out as a complement to this quantitative study and to extend the study's scope with a larger number of countries.

The study data did not indicate a higher level of board diversity in parent banks. An additional element to critical attitude towards the second hypothesis (H2) is the time difference in introduction of national diversity in boards: for subsidiary banks, the diversity began long before EU directives and even before the beginning of the source of diversity reform, the international financial crisis. The process of liberalization in Eastern Europe from the 1990s attracts bank groups from the EU and gives rise to a new form of boards' diversity in subsidiary banks — a supervisory board containing non-residents from the home country and a management board, whose members are residents of the host country.

Figure 6. Banks with adopted diversity policies in home countries, \%

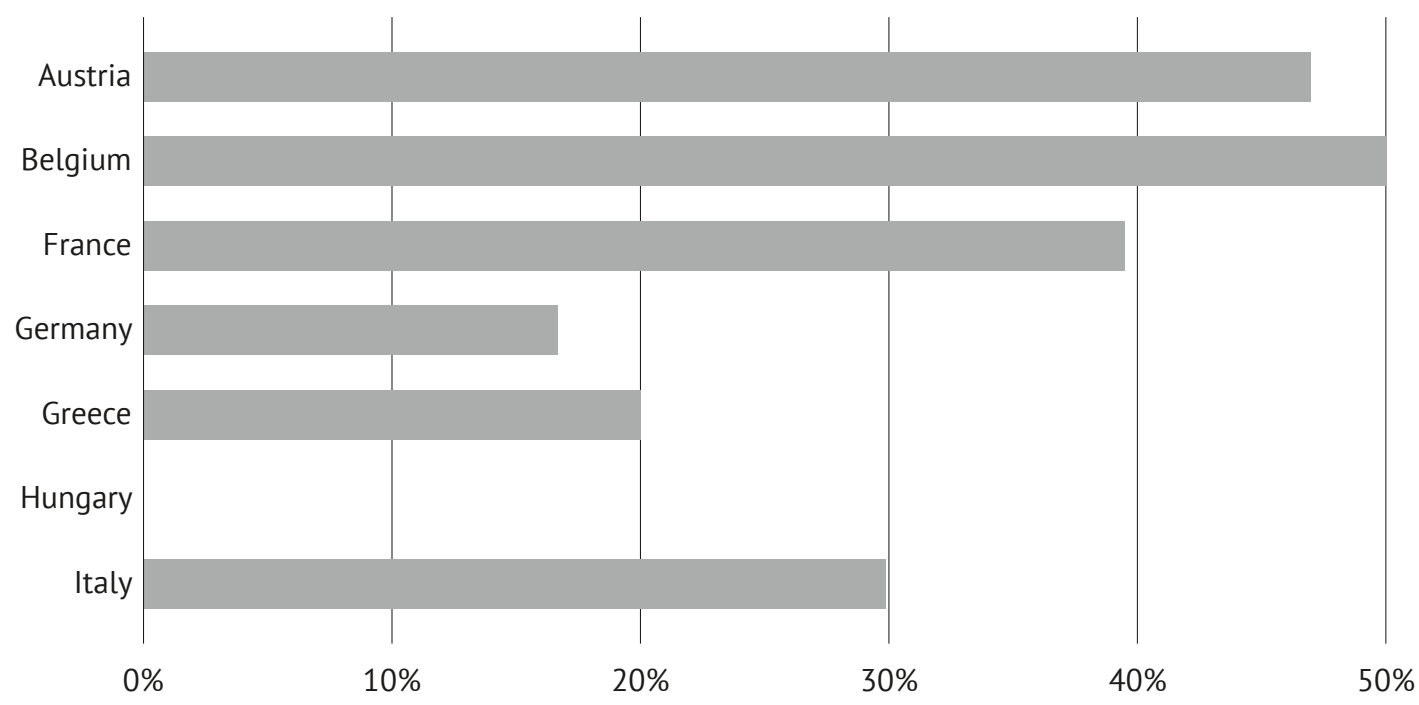

Source: European Banking Authority, 2017 
The matter of achieving diversity in nationality is specific for transnational banks, as only diverse boards are able to meet the needs of local customers and stakeholders (International Finance Corporation, 2015). However, in order to be successful in this direction, the boards of transnational banks must necessarily take into account the cultural values and the legislation in the host country.

The study shows that in Bulgarian banks, there is nationality diversity above the average level in their parent banks in their home country. The good results are due to the subordination of Bulgarian banks to the hierarchy of EU financial groups and, to a lesser extent, to the European directives. The place in the hierarchy defines the purpose of nationality diversity: for the parent banks, diversity reduces the risk while for the subsidiary banks - reducing of the agency problem.

The stabilization of the banking system and the prospects for EU membership led to an increase in foreign ownership in Bulgarian banks. The subordination of subsidiary banks in their bank groups explains the fact that in Bulgaria, the diversity of boards is introduced before implementation of a diversity policy in the EU. In other words, unlike other countries in Bulgaria, the board diversity is not a consequence of EU membership, but rather of the introduction of market economy and good corporate governance practices. While diversity is restricted to compliance with EU directives for parent banks, its ultimate goal in Bulgarian banks is to protect abroad investments.

The innovation of board diversity determines the difficulties in carrying out studies. The main challenge is the limited literature, which defines our study as a keystone for further benchmarking. The official data are mainly by competent authorities and specialized bodies that should be interpreted for their practical application. Finally, the study is limited in scope, as the first data for the EU are from 2016.

The recommendation for future diversity study is to develop quantitative measures for determination of effects described in the second part of this study. Additional recommendation is to be carrying out the same study for other countries with dominantly foreign ownership in its bank system. And finally, a comparative analysis of the results is recommended to be performed in Bulgaria and other countries to highlight national specifics.

\section{References}

Basel Committee on Banking Supervision (2010). Principles for enhancing corporate governance. Basel: Bank for International Settlements. Björklund, R. (2010). Corporate board governance \& the diversity-participation paradox - A note on the banking sector. International Journal of Public Information Systems, 6(1), 121-131.

Bulgarian National Bank (2017). Banks in Bulgaria. Sofia: BNB, January - March 2017.

Čančer, V. \& Mulej, M. (2013). Multi-criteria decision making in creative problem solving. Kybernetes, 42(1), 67-81. https://doi. org/10.1108/03684921311295484

Directive 2014/59/EU of the European Parliament and of the Council of 15 May 2014 establishing a framework for the recovery and resolution of credit institutions and investment firms and amending Council Directive 82/891/EEC, and Directives 2001/24/EC, 2002/47/EC, 2004/25/EC, 2005/56/EC, 2007/36/EC, 2011/35/EU, 2012/30/EU and 2013/36/EU, and Regulations (EU) No 1093/2010 and (EU) No 648/2012, of the European Parliament and of the Council

Directive 2014/65/EU of the European Parliament and of the Council of 15 May 2014 on markets in financial instruments and amending Directive 2002/92/EC and Directive 2011/61/EU

Directive 2013/36/EU of the European Parliament and of the Council of 26 June 2013 on access to the activity of credit institutions and the prudential supervision of credit institutions and investment firms, amending Directive 2002/87/EC and repealing Directives 2006/48/EC and 2006/49/EC.

European Banking Authority (2017).Joint ESMA and EBA Guidelines on the assessment of the suitability of members of the management body and key function holders under Directive 2013/36/EU and Directive 2014/65/EU. EBA/GL/2017/12

European Banking Authority (2016). Report on the benchmarking of diversity practices. EBA, London.

European Commission (2010). Green paper. Corporate governance in financial institutions and remuneration policies. COM(2010) 284 final.

European Commission (2011). The EU corporate governance framework. COM(2011) 164 final.

European Commission (2012). Action Plan: European company law and corporate governance - a modern legal framework for more engaged shareholders and sustainable companies. COM(2012) 740 final.

García-Mecaa, E., García-Sánchezb, I.-M., \& Martínez-Ferrerob, J. (2015). Board diversity and its effects on bank performance:An international analysis. Journal of Banking \& Finance, 53, 202-214. https://doi.org/10.1016/j.jbankfin.2014.12.002

Houbenova-Delisivkova, T. (2015). The financial sector in Bulgaria: Problems and challenges of the regulation and policies alternatives. In: Demarrage or Slow Motion for the Economy and Finance. Sofia: UNWE Printing House, 15-27.

International Finance Corporation (2016). The corporate secretary: The governance professional. Washington DC. https://doi. org/10.1596/25393

International Finance Corporation (2015). A guide to corporate governance practices in the European Union. Washington DC. 
International Finance Corporation (2012). Corporate governance for banks in Southeast Europe. Washington DC.

IIC Partners. (2015). Bio-diversity among European bank board members. San Francisco.

Nedelchev, M. (2017a). Diversity on bank boards: Evidence from Bulgaria. Ethical Boardroom, Summer, 52-54.

Nedelchev, M. (2017b). Diversity on banks' boards. Economic Thought Journal, 2, 71-91.

Pašić, P., Bratina, B., \& Festić, M. (2016). Corporate governance of banks in Poland and Slovenia. Naše gospodarstvo/Our Economy, 62(3), 3-12. https://doi.org/10.1515/ngoe-2016-0013

\section{Author}

Miroslav Nedelchev is a Chief Assist. Prof. at the Economic Research Institute at the Bulgarian Academy of Sciences. He holds a PhD in Banking from Sofia University and a PhD in International banking from Bulgarian Academy of Sciences. He is an author of studies in fields of corporate governance and member of projects for banking.

\section{Nacionalna raznolikost nadzornih svetov bank}

\section{Izvleček}

Namen prispevka je izvedba primerjalne študije o nacionalni raznolikosti nadzornih svetov bank. Študija zajema bančno prakso glede raznolikosti sestave nadzornih svetov devetih poslovnih bank v Bolgariji. Podatke primerjamo za podrejene banke v Bolgariji in njihove nadrejene kreditne institucije v matičnih državah.

Študija opredeljuje visoko stopnjo nacionalne raznolikosti v obravnavnih podrejenih bankah. Število tujih članov nadzornih svetov je v bolgarskih bankah višje kot v preučevanih nadrejenih kreditnih institucijah. Dobre prakse v zvezi z raznolikostjo $\checkmark$ teh organih bolgarskih bank so posledica njihove podrejenosti v evropskih finančnih konglomeratih in so namenjene zmanjšanju konfliktov interesov med agentom in principalom.

Ključne besede: korporativno upravljanje, podrejene banke, Bolgarija, primerjalna študija 